\title{
Pendampingan Guru dalam Pembelajaran Aspek Perkembangan Bahasa dan Aspek Sosial di TK Labschool Jember
}

\author{
Eky Prasetya Pertiwi ${ }^{1)}$ \\ ${ }^{1)}$ Institut Keguruan dan Ilmu Pendidikan PGRI Jember \\ eky.prasetya.pertiwi@gmail.com
}

\begin{abstract}
ABSTRAK: Aspek Bahasa dan aspek Sosial bagi anak usia dini sangat berpengaruh terhadap perkembangan jasmani maupun rohani. Sosial anak juga mempengaruhi bagaimana mereka bermain dan membentuk karakter anak. Seni merupakan salah satu faktor yang mempengaruhi aspek bahasa anak. Dalam berbahasa, dapat dituangkan dalam bentuk seni untuk menciptakan pembelajaran yang lebih menarik untuk anak usia dini. Menciptakan karya seni, anak usia dini akan diajarkan mengenal berbagai macam bahasa yaitu bahasa daerah diantaranya bahasa Jawa dan Madura, Bahasa Inggris serta bahasa Indonesia yang baik dan benar. Pemilihan bahasa ditentukan oleh latar belakang dan kondisi yang dibutuhkan saat anak bersosialisasi didaerah tersebut. Lokasi kegiatan pendampingan berada di Kota Jember yang mayoritas penduduk kota Jember adalah suku Madura dan suku Jawa. Pelaksanaan kegiatan ini dilaksanakan oleh mahasiswa IKIP PGRI Jember program studi PG.PAUD dengan menciptakan karya lagu dengan 3 bahasa yaitu, Madura, Jawa, dan bahasa Inggris yang dibimbing oleh dosen pembimbing. Hasil cipta karya seni ini akan membantu memberikan variasi dalam pembelajaran aspek perkembangan bahasa dan sosial anak usia dini. Pengenalan berbagai macam bahasa membantu anak mengenal berbagai macam bahasa yang ada di Negara Indonesia. Dengan mengenalkan variasi bahasa pada anak usia dini diharapkan anak dapat bersosialisasi dengan baik dengan teman sebayanya dan lingkungan sekitar.
\end{abstract}

Kata kunci : aspek bahasa, aspek sosial, pendampingan guru, anak usia dini.

ABSTRACT: Language and social aspects for early childhood are very influential on physical and spiritual development. Children's social also affects how they play and shape children's character. Art is one of the factors that influence aspects of children's language. In language, it can be expressed in the form of art to create more interesting learning for early childhood. Creating works of art, early childhood will be taught to know various languages, namely regional languages including Javanese and Madurese, English and Indonesian which are good and correct. The choice of language is determined by the background and conditions needed when children socialize in the area. The location of the assistance activities is in the City of Jember, where the majority of the population of Jember is Madurese and Javanese. The implementation of this activity was carried out by students of the IKIP PGRI Jember PG.PAUD study program by creating songs in 3 languages, namely, Madurese, Javanese, and English which were guided by their supervisors. The creation of this artwork will help provide variety in learning aspects of language development and early childhood social development. The introduction of various languages helps children get to know the various languages in Indonesia. By introducing language variations in early childhood, it is hoped that children can socialize well with their peers and the surrounding environment.

Keywords: aspects of language, social aspects, teacher assistance, early childhood.

\section{PENDAHULUAN}

Anak usia dini merupakan anak-anak pada rentang usia 0-6 tahun yang membutuhkan banyak stimulasi untuk membantu pertumbuhan dan perkembangan 
jasmani maupun rohaninya. Pada usia ini, pemberian stimulasi dimaksudkan untuk mengoptimalkan berbagai aspek perkembangan anak yang meliputi perkembangan nilai-nilai agama dan moral, sosial emosional, bahasa, kognitif, fisik motorik dan seni. Menurut Suhartono (2005:8) menyatakan bahwa dengan bantuan bahasa, anak tumbuh dari organisme biologis menjadi pribadi didalam kelompok. Pribadi itu berpikir, merasa, bersikap, berbuat serta memandang dunia dan kehidupan seperti masyarakat sekitarnya.

Bahasa mencakup segala bentuk komunikasi, baik yang diutarakan dalam bentuk lisan, tulisan, bahasa isyarat, bahasa gerak tubuh, ekspresi wajah pantonim atau seni. Sedangkan berbicara adalah bahasa lisan yang merupakan bentuk yang paling efektif untuk berkomunikasi dan paling penting serta paling banyak dipergunakan. Bahasa dapat juga diekspresikan melalui tulisan, tanda gestural dan musik. Oleh sebab itu seni tidak dapat dipisahkan dalam merangsang perkembangan anak usia dini. Pendidikan seni merupakan yang paling efektif untuk meningkatkan kreativitas disamping itu pendidikan seni menjadi sarana pendidikan afektif dalam kerangka mengakomodasi emosi dan ekspresi anak.

Menurut Budi (2011) fungsi pendidikan seni adalah, (1) pendidikan seni adalah sebagai media ekspresi, (2) pendidikan seni adalah sebagai media komunikasi, (3) pendidikan seni adalah sebagai media bermain, (4) pendidikan seni adalah sebagai media pengembangan bakat, dan (5) pendidikan seni adalah sebagai media kreativitas. Menurut Suryaningsih (2015) menyebutkan bahwa metode bernyanyi merupakan salah satu cara untuk menstimulasi perkembangan bahasa anak usia dini. Dengan bernyanyi dapat menambah kosakata anak usia dini sehingga dapat mengembangkan aspek perkembangan bahasa anak usia dini. Menurut Hidayat (2006) Tari merupakan juga sebuah seni kolektif karena didalamnya terdapat beberapa unsur, meliputi seni musik, seni sastra, seni rupa dan seni drama. Masing-masing bentuk seni mempunyai unsur yang dapat memberikan penjelasan dan ketegasan lebih bermakna mengenai bentuk seni tersebut.

Pengertian Tari dalam Hidayat (2006) antara lain sebagai berikut.

a. Menurut Curt Sach "Tari adalah gerakan yang ritmis (dance is rhythmic motion)". Pengertian ini mengisyaratkan bahwa gerakan itu lebih besar berkaitan dengan pola waktunya sebagai sebuah proses terbentuknya rangkaian tubuh yang bermakna.

b. Menurut Dr. J. Verkuyl menekankan pada gerak anggota badan (tubuh keteraturan dan irama. "Tari adalah gerak-gerik tubuh dan anggota-anggotanya yang diatur sedemikan rupa sehingga berirama".

c. Menurut Crawiey, Tari adalah pernyataan gerak interaktif dari urat mengenai perasaan. Pengertian tersebut menunjukkan bahwa tari sangat berurusan dengan perasaan, sensitivitas jiwa yang reaksional dengan menanggapi suatu stimulus dari luar atau reaksi spontan dari dalam diri manusia.

d. Menurut Wisnoe Wardana salah satu tokoh tari modern Indonesia yang mengartikan Tari adalah kerja rasa yang penyalurannya melewati urat-urat. 
Pemahaman tentang gerak dan didalamnya secara implisit terdiri dari otot dan atau urat tubuh yang bersifat teknis.

e. Menurut RM. Soedarsono dalam bukunya Djawa dan Bali; Dua pusat perkembangan Drama tari Tradisional di Indonesia, yang mengartikan tari adalah ekspresi jiwa manusia yang diungkapkan melalui gerak-gerak ritmis dan indah.

f. Menurut Bagong Kusudiarjo, Tari adalah keindahan bentuk dari anggota badan manusia yang bergerak, berirama dan berjiwa yang harmonis.

Berdasarkan deskripsi diatas, maka dalam suatu karya seni baik bernyanyi maupun tari dapat mengajarkan banyak hal pada anak-anak terutama dalam pembelajaran aspek bahasa. Untuk mengenalkan berbagai macam bahasa pada anak usia dini maka dapat diperkenalkan juga melalui nyanyian dan tarian yang dapat bertujuan untuk menumbuh kembangkan aspek keterampilan anak terutama dalam aspek bahasa dan seni.

\section{PERMASALAHAN}

Menciptakan karya seni, anak usia dini akan diajarkan mengenal berbagai macam bahasa yaitu bahasa daerah diantaranya bahasa Jawa dan Madura, bahasa inggris serta bahasa Indonesia yang baik dan benar. Pemilihan bahasa ditentukan oleh latar belakang dan kondisi yang dibutuhkan saat anak bersosialisasi didaerah tersebut. Lokasi pengabdian berada di kota Jember yang mayoritas penduduk kota Jember bagian utara adalah suku Madura dan bagian selatan serta di pesisir pantai merupakan suku Jawa. Pelaksanaan kegiatan ini dilaksanakan oleh mahasiswa IKIP PGRI Jember program studi PG.PAUD yang dibimbing oleh dosen pembimbing. Atas dasar hal tersebut maka, pemilihan pengenalan bahasa jawa dan Madura dipilih untuk dikenalkan dalam bentuk nyanyian. Sedangkan untuk pengenalan dalam bahasa inggris di kenalkan hanya pada lima huruf, karena bahasa inggris merupakan bahasa Internasional maka untuk pembelajaran pada anak usia dini diberikan sedikit mengenai huruf vokal.

\section{METODE PELAKSANAAN}

Kegiatan tersebut diimplementasikan di TK Lab School JEMBER yang beralamat di Jalan Jawa no 10 Jember. Waktu penciptaan karya seni tari/gerak dan syair lagu dilakukan di kampus IKIP PGRI Jember pada awal bulan Desember tahun 2019 selama satu bulan. Sedangkan pelaksanaan implementasi pada Anak Usia Dini dilakukan pada akhir bulan Desember 2019. Sasaran dari kegiatan pendampingan guru adalah guru beserta anak-anak didik di TK Labschool Jember. Beberapa tahapan pelaksanaan kegiatan disajikan dalam Tabel 1. 
Tabel 1. Tahapan pelaksanaan kegiatan pendampingan

\begin{tabular}{|c|c|c|}
\hline No. & Tahapan & Uraian Kegaiatan \\
\hline 1. & Persiapan Kegiatan & $\begin{array}{l}\text { a. Menciptakan Syair atau kalimat dalam bahasa } \\
\text { yang sederhana, pengkoreksian/bimbingan } \\
\text { mengenai bahasa yang digunakan/yang akan } \\
\text { diperkenalkan serta mengidentifikasi mengenai } \\
\text { pesan moral yang akan disampaikan pada Anak } \\
\text { Usia Dini. } \\
\text { b. Permohonan ijin kegiatan pengabdian } \\
\text { masyarakat kepada Kepala PAUD LabSchool } \\
\text { IKIP PGRI Jember. } \\
\text { c. Praktek penggunaan bahasa. } \\
\text { d. Praktek penggunaan bahasa dan gerak tari secara } \\
\text { spontan. } \\
\text { e. Persiapan implementasi pada anak-anak didik } \\
\text { di TK Labschool Jember. }\end{array}$ \\
\hline 2. & $\begin{array}{l}\text { Kegiatan pengimplementasian } \\
\text { mengenai pengenalan bahasa } \\
\text { melalui gerakan/tari pada anak } \\
\text { usia dini. }\end{array}$ & $\begin{array}{l}\text { a. Pembukaan oleh ibu kepala sekolah. } \\
\text { b. Implementasi Pengenalan Bahasa melalui Gerak } \\
\text { Tari. }\end{array}$ \\
\hline 3. & Kegiatan Akhir & $\begin{array}{l}\text { a. Pemberian respon pada anak usia dini di TK } \\
\text { Labschool Jember berupa ajakan menari } \\
\text { bersama. } \\
\text { b. Foto bersama. }\end{array}$ \\
\hline 4. & $\begin{array}{l}\text { Pembuatan laporan kegiatan } \\
\text { pengabdian masyarakat. }\end{array}$ & $\begin{array}{l}\text { Bimbingan laporan kegiatan kepada Dosen } \\
\text { pembimbing. }\end{array}$ \\
\hline
\end{tabular}

\section{PELAKSANAAN}

Jenis kegiatan yaitu pengabdian masyarakat yang berupa pendampingan guru dalam pembelajaran perkembangan aspek bahasa dan sosial berupa penciptaan karya seni oleh mahasiswa IKIP PGRI Jember program studi S1 PG.PAUD. Pelaksanaan kegiatan pendampingan pemberdayaan masyarakat yang dilakukan adalah berupa pendampingan yang berupa pembuatan karya seni, menciptakan syair, pemilihan bahasa serta adanya pemilihan pesan moral yang dilakukan serta penciptaaan gerak tari. 


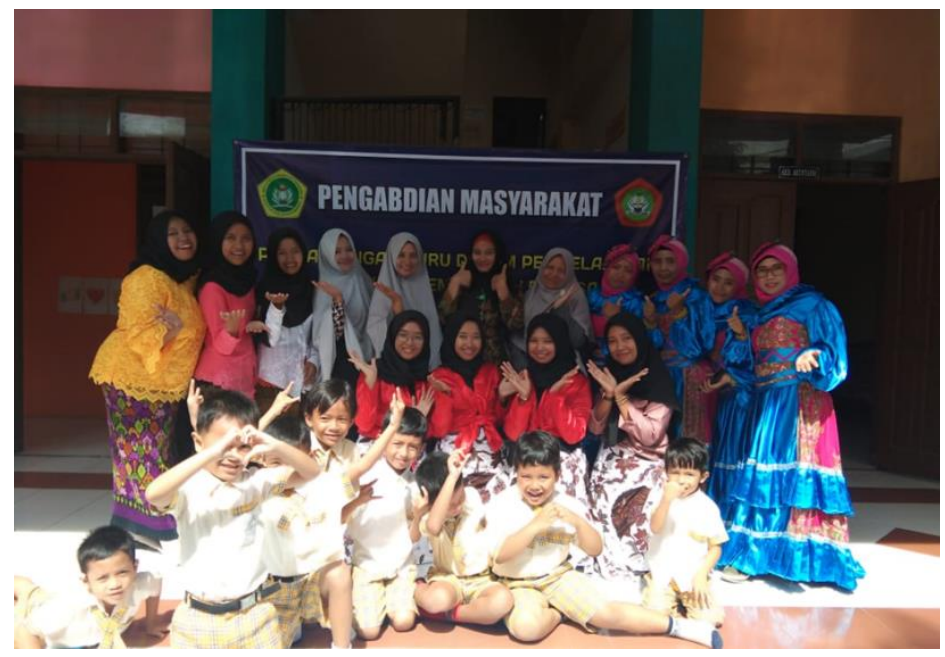

Gambar 1. Dosen pendamping, Mahasiswa, dan Siswa TK Labschool Jember

Pendamping berusaha mengamati setiap kegiatan tahap demi tahap. Mulai dari perencanaan dan pelaksanaan kegiatan pendampingan. Pendamping memberi catatan berupa baik dan buruknya selama proses kegiatan berlangsung. Catatan tersebut akan dapat bermanfaat sebagai koreksi untuk melaksanakan kegiatan pemberdayaan masyarakat dilingkungan PAUD kedepannya. Adapun hal - hal yang perlu diperhatikan dalam memberdayakan masyarakat di lingkungan PAUD diantaranya adalah memberikan variasi terhadap pembelajaran pada aspek perkembangan bahasa dan aspek sosial pada anak usia dini.

Penciptaan karya seni dibagi menjadi tiga kelompok mahasiswa yang disajikan dalam Tabel 2.

Tabel 2. Pembagian kelompok penciptaan lagu

\begin{tabular}{lll}
\hline No. & \multicolumn{1}{c}{ Kelompok } & \multicolumn{1}{c}{ Keterangan } \\
\hline 1. & Ibu Eky Prasetya Pertiwi, S.Sos., M.Si & Dosen Pendamping Kegiatan \\
\hline 2. & Kelompok 1 : (Shisca, Devi, Pawestri) & $\begin{array}{l}\text { Pembelajaran gerak tari dan } \\
\text { pengenalan bahasa Jawa }\end{array}$ \\
\hline 3. & $\begin{array}{l}\text { Kelompok 2: (Nabilah, Juhai, Siti Nurul, } \\
\text { Fitriyatus) }\end{array}$ & $\begin{array}{l}\text { Pembelajaran gerak tari dan } \\
\text { pengenalan bahasa Madura }\end{array}$ \\
\hline 4. & Kelompok 3: (Agustimurwati, Siti & $\begin{array}{l}\text { Pembelajaran gerak tari dan } \\
\text { pengenalan bahasa Inggris }\end{array}$ \\
\hline
\end{tabular}

\section{HASIL DAN LUARAN}

Gladi bersih dilakukan sebelum tahap implementasi di TK Labschool Jember. Kegiatan ini merupakan kegiatan praktik langsung dan pelaksana kegiatan pengabdian memberikan evaluasi secara langsung mengenai lirik, pengucapan dan gerak tari 
spontan yang dihasilkan. Hasil evaluasi kegiatan pada saat implementasi antara lain sebagai berikut.

a. Dari sisi penampil kegiatan (mahasiswa), sudah memberikan gerakan yang bagus dan pengucapan bahasa yang disampaikan anak-anak sudah baik. Anakanak sangat senang dan mengikuti kegiatan tersebut dengan aktif dan semangat.

b. Meskipun sebagian anak ada yang masih saja diam saat di rangsang melalui pertanyaan masih ada anak yang malu tetapi sebagian anak sudah percaya diri dengan mengikuti gerak dan lagu yang telah di terapkan oleh mahasiswa.

Karena adanya pandemic Covid-19 pada awal tahun 2020, maka kegiatan implementasi tidak bisa diteruskan sementara di semester selanjutnya. Sehingga kegiatan pengabdian ini hanya sebatas pada penciptaan karya seni, serta implementasi hasil penciptaan karya seni saja.

Berikut adalah hasil penciptaan seni berupa lagu yang diterapkan oleh kelompok mahasiswa 1, 2, dan 3 .

Kelompok 1 (versi Jawa).

\section{Judul : Nuwun Sewu}

Kula mlampah alon-alon

Yen wonten tiang-tiang sepuh

Mature nuwun sewu

Mature nuwun sewu

Amergi niku adat jawi

Kula ngendika alon-alon

Yen nyuwun ijin teng ibu guru

Mature nuwun sewu

Mature nuwun sewu

Amergi niku adat jawi

Kelompok 2 (versi Madura).

Judul : Mengenalkan Rukun Islam

Dining rukunah islam panikah lemak perkarah, sewejib e lakonin ummat islam sadejenah

se nomer settong koduh macah duek syahadat

se nomer due' lakoh sholat lemah bektoh

se nomer tellok koduh apareng zakat

se nomer empak koduh apasah e bulen romadhon

se nomer lemak onggeh haji de' baitullah

bileh ampon cokop ongkos jelenah tor molenah. 
Kelompok 3 (versi bahasa Inggris).

\section{Judul : Pengenalan Huruf Vokal}

Let's go my friends

We are studying alphabet

What the alphabet is that?

That is vowel

Let's go my friends

We are studying alphabet

What the alphabet is that?

That is vowel

$A, i, u, e, o$

That....... It is sound

$A, i, u, e, o$

That it is alphabet

Output yang didapat dari kegiatan pengabdian masyarakat ini diantaranya untuk merangsang perkembangan anak dalam aspek pembelajaran bahasa dan sosial pada anak usia dini. Sedangkan outcome yang didapatkan diantaranya adalah agar anak mampu meningkatkan keterampilan berbahasanya sehingga hasil belajar anak bisa lebih optimal serta diharapkan guru mampu meningkatkan kemampuan dalam mengelola kelas melalui metode bernyanyi dan menari, sehingga anak anak dalam berbahasa atau berbicaranya lebih optimal.

Kegiatan pendampingan guru melalui aspek perkembangan bahasa dan sosial pada anak usia dini melalui metode bernyanyi dan menari diharapkan akan diimplementasikan sendiri pada anak-anak TK Labschool Jember. Pengurus sekolah juga mengharapkan akan adanya kegiatan yang berkelanjutan sehingga semakin dapat meningkatkan berbagai macam pembelajaran yang bervariasi.

\section{KESIMPULAN}

Metode pelaksanaan kegiatan pendampingan guru yang dilakukan di TK Labschool Jember diantaranya berupa penciptaan karya seni, pembimbingan serta gladi bersih (praktek awal) dan implementasi ke TK Labschool Jember. Kegiatan pendampingan guru dalam menciptakan seni untuk Anak Usia Dini pada aspek pembelajaran perkembangan bahasa dan sosial yang dilakukan di TK Labschool Jember berjalan dengan baik. Dengan terciptanya karya seni ini akan membantu memberikan variasi dalam pembelajaran aspek perkembangan bahasa dan sosial anak usia dini. Pengenalan berbagai macam bahasa membantu anak mengenal berbagai macam bahasa yang ada di Negara Indonesia. Dengan mengenalkan variasi bahasa pada anak usia dini diharapkan anak dapat bersosialisasi dengan baik dengan teman sebayanya dan lingkungan sekitar. 


\section{DAFTAR PUSTAKA}

Budi, S. 2011. Pendidikan Seni Rupa. Surakarta: Universitas Muhammadiyah Surakarta.

Hidayat, R. 2006. Menerobos Pembelajaran Tari Pendidikan. Malang: Banjar Seni Gantar.

Suhartono. 2005. Pengembangan keterampilan bicara anak usia dini. Jakarta: Depdiknas.

Suryaningsih. 2015. Pengaruh Metode Bernyanyi Terhadap Perkembangan Bahasa Anak Usia Dini Di Lembaga PAUD Melati II Madiun Tahun Ajaran 2015/2016. Prosiding Seminar Nasional Pendidikan: Surakarta. 